\title{
Rapid and specific detection of the thermostable direct haemolysin gene in Vibrio parahaemolyticus by the polymerase chain reaction
}

\author{
Chiayin LeE* and Shwu-Fen Pan \\ Graduate Institute of Agricultural Chemistry, National Taiwan University, Taipei, Taiwan, Republic of China
}

(Received 17 March 1993; revised 25 June 1993; accepted 27 July 1993)

\begin{abstract}
Synthetic oligonucleotide primers derived from a sequence of the thermostable direct haemolysin $(t d h)$ gene were used in a polymerase chain reaction (PCR) amplification technique to detect this gene in strains of Vibrio parahaemolyticus. A total of 36 TDH-producing, and 89 TDH-negative Vibrio parahaemolyticus strains and 46 other vibrios and enteric pathogens were studied. In all, 36 strains of Vibrio parahaemolyticus from which the $t d h$ gene could be successfully amplified by PCR were found to be TDH-positive in TDH haemolysin assay. No amplification products were obtained from Vibrio parahaemolyticus strains that were TDH-negative in the haemolysin assay or from other vibrios and enteric pathogens, with the exception of two strains. The PCR results were consistent with DNA hybridization tests. The detection limit for the $t d h$ gene by PCR amplification was $40 \mathrm{pg}$ of total DNA, or broth culture containing 1000 viable cells. Amplification products were confirmed by restriction enzyme digestion and Southern blot hybridization. The PCR method could detect the $t d h$ sequences in stool samples from patients with gastroenteritis caused by $V$. parahaemolyticus. This PCR protocol clearly identified TDHproducing strains of $V$. parahaemolyticus and provides an alternative to conventional methods for TDH detection by research laboratories, clinical laboratories, regulatory agencies, and the seafood industry.
\end{abstract}

\section{Introduction}

Vibrio parahaemolyticus is a halophilic bacterium which is widely distributed in the marine environment and is a major causative agent of food infection in Taiwan (Chiou et al., 1991). Several kinds of haemolysins have been reported as potential pathogenic factors (Honda et al., 1989; Nishibuchi et al., 1985; Sarkar et al., 1987; Taniguchi et al., 1985, 1990). Among them, thermostable direct haemolysin (TDH) is almost exclusively associated with clinical strains and has been considered an important virulence factor (Miwatani \& Takeda, 1976). Therefore, rapid and accurate diagnostic tests are needed for routinely examining isolates of $V$. parahaemolyticus for their TDH-producing ability by both the food industry and clinical laboratories.

The ability to produce $\beta$-type haemolysis around colonies on Wagatsuma blood agar (a special blood medium) is used traditionally to determine the pro-

*Author for correspondence. Tel. +88623630231 ext. 2800; fax +88623633123 .

Abbreviations: TDH, thermostable direct haemolysin; TRH, TDH-related haemolysin. duction of TDH by $V$. parahaemolyticus (Miyamoto et al., 1969). An enzyme-linked immunosorbent assay (ELISA) for detection of TDH-producing strains of $V$. parahaemolyticus has also been reported (Honda et al., 1989). However, the blood agar test is not easily determined and may give false negative results. DNA probes and oligonucleotide probes specific for the gene encoding TDH and TDH-related haemolysin (TRH) have been described and used as hybridization probes (Nishibuchi et al., 1985, 1986; Yamamoto et al., 1992). However, the $t d h$ probes also hybridized with $t d h$-like genes possessed by $V$. hollisae, $V$. mimicus and $V$. cholerae non-O1.

Most of these tests are based on a pure culture of the suspected bacterium; thus, a tedious process of isolation of a pure culture limits the efficiency of diagnosis. Recently, a sensitive and rapid technique, the polymerase chain reaction (PCR), has been used directly to identify the presence of specific genes in microbial pathogens, and has been applied successfully in epidemiological studies (Kato et al., 1991; Pollard et al., 1990; Stein \& Raoult, 1992; Victor et al., 1991).

In the present study, we report the development of a PCR technique that can rapidly and specifically detect haemolysin genes $(t d h)$ in strains of haemolytic 
Table 1. Synthetic oligonucleotides used as primers for PCR

\begin{tabular}{clc}
\hline \hline & \multicolumn{1}{c}{$\begin{array}{c}\text { Sequence } \\
\left(5^{\prime}-3^{\prime}\right)\end{array}$} & $\begin{array}{c}\text { Corresponding } \\
\text { positions } \\
\text { in } t \text { th gene* }\end{array}$ \\
\hline Primers & GGT CAA GTA CAA CTT CAA CAT TCC & $615-638$ \\
VP12 & CCA CTA CCA CTC TCA TAT GC & $735-754$ \\
VP21 & TGG TTG ACA TCC TAC ATG ACT GTG & $513-536$ \\
VP22 & GGG GAT CCC TCA GTA CAA AGC CTT & $889-912$ \\
\hline \hline
\end{tabular}

* The nucleotide sequence of $t d h$ gene was reported by Nishibuchi et al. (1985).

$V$. parahaemolyticus associated with human gastroenteritis. The oligonucleotide primers used in the PCR procedure are derived from the nucleotide sequence of the $t d h$ gene of $V$. parahaemolyticus (Nishibuchi \& Kaper, 1985). The specificity of these primers was evaluated by using PCR with a collection of reference strains and Vibrio spp. isolated from human and environmental sources. The PCR results were also compared with DNA hybridization tests and immunological assays for TDH production. Finally, a successful application of the PCR method to the detection of $V$. parahaemolyticus in stool samples was demonstrated.

\section{Methods}

Bacterial strains and culture media. V. parahaemolyticus isolates used in this study included the following strains: ATCC 17802 (obtained from the American Type Culture Collection, Rockville, MD, USA); A92 $\left(t d h^{+}, t r h^{-}\right)$, A220 $\left(t d h^{-}, t r h^{+}\right)$and A326 $\left(t d h^{-}, t r h^{-}\right)$(obtained from M. Nishibuchi, Dept. of Microbiology, Faculty of Medicine, Kyoto University, Japan); 87 environmental and 38 clinical strains originally isolated in the Taiwan area.

To determine the specificity of PCR for $V$. parahaemolyticus, DNA was isolated from the following micro-organisms: $V$. cholerae, $V$. cholerae non-O1, V. hollisae, V. alginolyticus (ATCC 17749), $V$. damsela, V. mimicus, $V$. campbellii (ATCC 25920), V. vulnificus (ATCC 33147), $\quad V . \quad$ costicola (ATCC 33508), V. natriegens (ATCC 14048), V.percolans, V. diazotrophicus (ATCC 33466), V. logei (ATCC 15382), V. pelagius (ATCC 25916), Escherichia coli, Salmonella typhi (ATCC 6539), Salmonella typhimurium, Micrococcus luteus (ATCC 9341), Staphylococcus aureus (ATCC 6538P), Klebsiella pneumoniae (ATCC 10031), Pseudomonas aeruginosa and Proteus mirabilis. Other vibrios and tested bacteria used in this study were laboratory stock strains from the Department of Agricultural Chemistry, National Taiwan University.

Tryptic soy agar (TSA) (Difco) or tryptic soy broth (TSB) (Difco) supplemented with $3 \%(\mathrm{w} / \mathrm{v}) \mathrm{NaCl}$ were used for growth of all the Vibrio spp. Other bacterial cultures were grown on TSA or TSB medium.

Collection of stool samples. Stool samples from patients with acute diarrhoea were collected by rectal swabs. All stool samples were enriched in alkaline peptone water $[1 \%(\mathrm{w} / \mathrm{v})$ peptone, $3 \% \mathrm{NaCl}$, $\mathrm{pH}$ 8.4] for $6 \mathrm{~h}$ and were examined immediately at the National Institute of Preventive Medicine, Department of Health, Taiwan, for $V$. parahaemolyticus by using thiosulphate/citrate/bile/sucrose agar (Difco). The stool samples were then transported to our laboratory, diluted with distilled deionized water and were subjected to the PCR assay with primers VP21 and VP22.

$T D H$ assay. TDH production by $V$. parahaemolyticus was determined by bead ELISA (Nissui). $V$. parahaemolyticus strains were grown overnight in $3 \mathrm{ml} \mathrm{TSB} / 3 \% \mathrm{NaCl}$ with shaking at $37^{\circ} \mathrm{C}$; culture supernatants were obtained by microcentrifugation (3000 r.p.m.) and passed through $0.22 \mu \mathrm{m}$ pore-size cellulose acetate membrane filters (Lida). The detection procedures were performed according to the manufacturer's instructions. The intensity of the colour reaction was measured spectrophotometrically at $450 \mathrm{~nm}$ (Hitachi U2000).

Synthetic oligonucleotide primers. Two oligonucleotide primers were synthesized (Bio-Synthesis) according to the published DNA sequence of the gene encoding the TDH of $V$. parahaemolyticus (Nishibuchi \& Kaper, 1985). Primers chosen in this study were directed at the presence of heterologous sequences between the $t d h$ and $t r h$ genes in the targeted region (Nishibuchi et al., 1989). The sequences of the primers and the homologous sites for hybridization to $t d h$ are shown in Table 1.

DNA hybridization test. Clinical and environmental strains of $V$. parahaemolyticus and related organisms were examined for the $t d h$ gene by colony or dot hybridization tests. A specific gene probe encoding an internal portion of the $t d h$ gene (Nishibuchi et al., 1985) was isolated and purified as reported previously (Shirai et al., 1990). DNA probes were labelled using a random primed DNA labelling kit (Boehringer-Mannheim) with ${ }^{32} \mathrm{P}$-labelled dCTP (Feinberg \& Vogelstein, 1984).

Colonies of bacteria were transferred to Colony/Plaque Screen Discs (Du Pont) by overlaying the filter on the agar surface for $2 \mathrm{~min}$; other procedures were performed according to the manufacturer's instructions. Colony hybridization was done at $65^{\circ} \mathrm{C}$ overnight in $1 \%(\mathrm{w} / \mathrm{v})$ $\mathrm{SDS} / 1 \mathrm{M}-\mathrm{NaCl} / 10 \%(\mathrm{w} / \mathrm{v})$ dextran sulphate. After hybridization, the membranes were rinsed twice with $2 \times \mathrm{SSC}(1 \times \mathrm{SSC}$ is $0.15 \mathrm{M}-\mathrm{NaCl}$, $0.015 \mathrm{M}$-trisodium citrate, $\mathrm{pH} 7.0$ ) at $25^{\circ} \mathrm{C}$ for $5 \mathrm{~min}$ and then rinsed twice with $2 \times \mathrm{SSC} / 1 \% \mathrm{SDS}$ at $65^{\circ} \mathrm{C}$ for $30 \mathrm{~min}$. The last wash was done twice in $0.1 \times \mathrm{SSC}$ at $25^{\circ} \mathrm{C}$ for $30 \mathrm{~min}$

Bacterial chromosomal DNA was heated at $100^{\circ} \mathrm{C}$ for $10 \mathrm{~min}$ and was then loaded on the Zeta-probe membrane using a Bio-Dot microfiltration apparatus (Bio-Rad). The membrane was dried and hybridized at $65^{\circ} \mathrm{C}$ overnight in $1.5 \times \operatorname{SSPE}(1 \times \operatorname{SSPE}$ is $0.18 \mathrm{M}-\mathrm{NaCl}$, $0.01 \mathrm{M}$-sodium phosphate, $0.01 \mathrm{M}$-disodium-EDTA), $1 \%$ SDS, $0.5 \%$ Blotto (non-fat dry milk, Carnation) and $0.5 \mathrm{mg}$ denatured herring sperm DNA ml ${ }^{-1}$ (Boehringer Mannheim). After hybridization, the membrane was rinsed with $2 \times \mathrm{SSPE}, 2 \times \mathrm{SSPE} / 0 \cdot 1 \% \mathrm{SDS}$, followed by $0.5 \times \mathrm{SSPE} / 0.1 \% \mathrm{SDS}$ and $0.1 \times \mathrm{SSPE} / 0.1 \% \mathrm{SDS}$, at $25^{\circ} \mathrm{C}$ for $15 \mathrm{~min}$. The last wash was done in $0.1 \times \mathrm{SSPE} / 1 \% \mathrm{SDS}$ at $65^{\circ} \mathrm{C}$ for $30 \mathrm{~min}$, followed by rinsing with $0 \cdot 1 \times \mathrm{SSPE}$. After hybridization, the colony blot or dot blot membranes were autoradiographed using $\mathrm{X}$-Omat film (Eastman Kodak) with intensifying screens and exposure at $-70^{\circ} \mathrm{C}$ for an appropriate length of time. 
Preparation of samples for PCR analysis. All samples were prepared in three ways. The first method was based on the method for the minipreparation of chromosomal DNA described by Ausubel et al. (1987). Bacterial chromosomal DNA was extracted by SDS/proteinase $\mathrm{K}$ lysis, followed by hexadecyltrimethyl ammonium bromide (CTAB) treatment, two extractions with phenol/chloroform/isoamyl alcohol and absolute ethanol precipitation. The purified DNA was then suspended in small volumes of TE buffer $[10 \mathrm{~mm}-\mathrm{Tris} / \mathrm{HCl}(\mathrm{pH} 8)$, $1 \mathrm{mM}$-EDTA]. The second method was lysing $1 \mathrm{ml}$ samples of the bacterial suspension with $1 \mathrm{mg}$ lysozyme $\mathrm{ml}^{-1}$ (final concentration) (Sigma) at room temperature for $15 \mathrm{~min}$, followed by digestion with $200 \mu \mathrm{g}$ proteinase $\mathrm{K} \mathrm{ml}^{-1}$ (final concentration) (Boehringer Mannheim) at $60{ }^{\circ} \mathrm{C}$ for $30 \mathrm{~min}$, and then boiling for $10 \mathrm{~min}$. The third method was using freshly grown bacterial cells instead of genomic DNA as a template in the PCR procedure.

PCR amplification. The PCR solution contained $1 \times$ PCR amplification buffer $(50 \mathrm{~mm}-\mathrm{KCl}, 10 \mathrm{~mm}-\mathrm{Tris} / \mathrm{HCl}, 0.1 \%$ Triton $\mathrm{X}-100)$, $1.5 \mathrm{~mm}-\mathrm{MgCl}_{2}$, deoxynucleoside triphosphates at $200 \mu \mathrm{M}$ each, primers at $1 \mu \mathrm{M}$ each, 1.25 U Taq DNA polymerase (Promega), $5 \mu$ l of template DNA (40 ng) or bacterial broth and double-distilled water treated with $0.1 \%$ diethylpyrocarbonate to make a final volume of $50 \mu \mathrm{l}$. The mixtures were overlaid with $50 \mu \mathrm{l}$ of mineral oil (Sigma) and subjected to 25 PCR cycles in a Programmable Temperature Cycler (ASTEC PC700). Parameters for the amplification cycles were denaturation for $1 \mathrm{~min}$ at $94^{\circ} \mathrm{C}$, annealing of primers for $1 \mathrm{~min}$ at $55^{\circ} \mathrm{C}$, and primer extension for $1 \mathrm{~min}$ at $72^{\circ} \mathrm{C}$. After the last cycle, the PCR mixtures were incubated for $10 \mathrm{~min}$ at $72^{\circ} \mathrm{C}$.

Detection of PCR products. PCR-amplified DNAs were detected by using gel electrophoresis [ $2 \%(\mathrm{w} / \mathrm{v})$ agarose gel]. Ten microlitres each of the amplification mixture and molecular mass markers (Hinf I digest of pBR322 DNA) were subjected to electrophoresis and ethidium bromide staining. The specific amplified DNA fragments were visualized by UV illumination.

Southern blot hybridization. For confirmation of the amplified DNA by Southern blot hybridization, $10 \mu \mathrm{l}$ of PCR products were subjected to $2 \%$ agarose gel electrophoresis and then transferred to a Zeta-probe membrane (Bio-Rad) by alkaline Southern blotting (Reed \& Mann, 1985). A 26-mer synthetic oligonucleotide (5'-GCT AAG TTT GTT GGT GAA GAT GAA GG-3') (VP5) corresponding to positions 651 to 676 in the published nucleotide sequence of the $t d h$ gene (Nishibuchi \& Kaper, 1985) was labelled with [ $\gamma^{32}{ }^{32}$ P]ATP by $5^{\prime}$ end-labelling using T4 polynucleotide kinase (Bethesda) as a probe $\left(10^{6}\right.$ c.p.m. $\left.\mathrm{ml}^{-1}\right)$. Southern blot hybridization followed the same procedure as dot blot hybridization, except the temperature of both the hybridization and the last wash was held at $40^{\circ} \mathrm{C}$ instead of $65^{\circ} \mathrm{C}$.

Restriction endonuclease digestion. Samples $(10 \mu \mathrm{l})$ of PCR products were subjected to restriction endonuclease digestion with Hinf I (Bethesda) as recommended by the manufacturer. The digested samples were analysed by $2 \%$ agarose gel electrophoresis.

\section{Results}

Detection of th gene in $V$. parahaemolyticus by PCR

The optimization of the PCR method with purified chromosomal DNA from $V$. parahaemolyticus was evaluated by using VP11-VP12 and VP21-VP22 two primers sets, with nine representative strains of $V$. parahaemolyticus. Of the nine strains; five had both the $t d h$ and $t r h$ genes; one was $t d h^{+} t r h^{-}$(A92); one was $t d h^{-} t r h^{+}$(A220) and two were $t d h^{-} t r h^{-}(\mathrm{A} 326,119)$. The
PCR results showed that primers VP21 and VP22 specifically amplify the $t d h$ gene only under the conditions described in Methods, and not the trh gene. The results also showed that VP21-VP22 primers can differentiate the presence or absence of the $t d h$ gene in $V$. parahaemolyticus (Fig. 1a). An amplified DNA product of $400 \mathrm{bp}$ was predicted from the design of the primers, and this was produced by the representative $t d h^{+}$strains of $V$. parahaemolyticus. However, the VP11-VP12 primers did not give specific amplified fragments in this study.

Southern blot hybridization with an internal oligonucleotide DNA probe showed that the 400 bp DNA fragments from $t d h^{+} V$. parahaemolyticus could hybridize with the oligonucleotide probe that was derived from the sequence located between the two primers, VP21 and VP22 (Fig. 1b). This result revealed that the $400 \mathrm{bp}$ fragment was a $t d h$-specific sequence, and that no other fragment homologous to the $t d h$ gene was amplified.

Digestion of the $400 \mathrm{bp}$ amplification product at the HinfI sites yielded two fragments of 274 and 126 bp (Fig. 2 ). This digestion produced the expected fragments, and the restriction patterns were identical for all six TDHproducing strains of $V$. parahaemolyticus. These results strongly suggest that the amplified DNA contains $t d h$ sequences of $V$. parahaemolyticus.

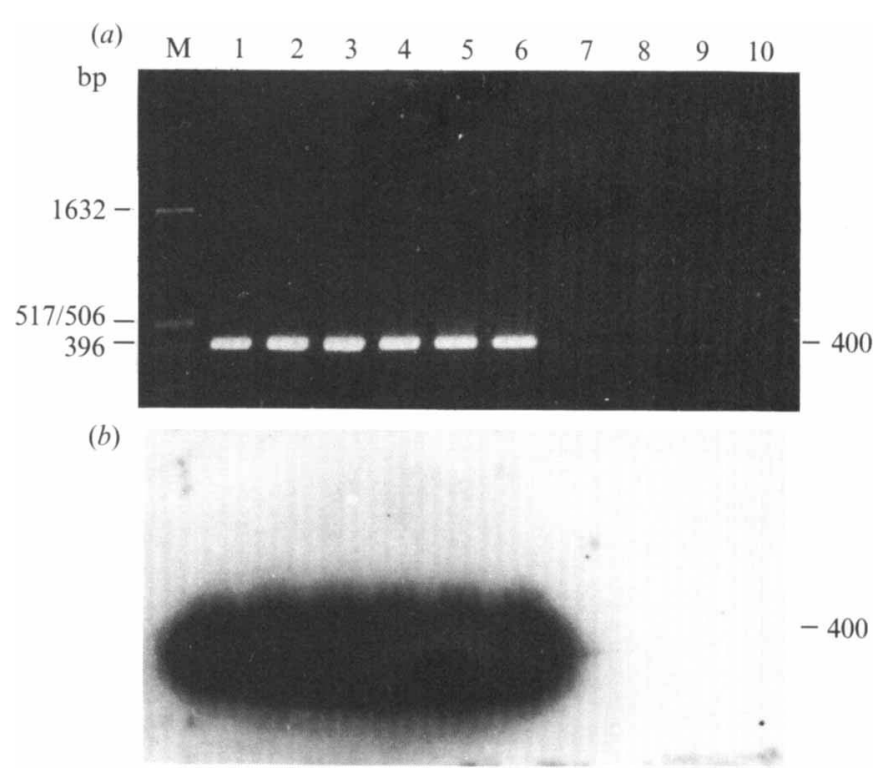

Fig. 1. Specific amplification of $400 \mathrm{bp}$ fragments from total DNAs of $V$. parahaemolyticus by PCR with $t d h$ gene primers. ( $a$ ) Agarose gel electrophoresis of PCR product. (b) Southern blot analysis of the products probed with VP5. Lanes: M, molecular size markers (pBR322 digested with $H \inf \mathrm{I}) ; 1$, V. parahaemolyticus A92 as positive control; 2-6, five $V$.parahaemolyticus strains which had the $t$ dh gene (nos 14, 17, 58,59 and 60 , respectively); 7-9, three $V$. parahaemolyticus strains which lacked the $t d h$ gene (A220, A326, no. 119, respectively); 10, reagent control. 


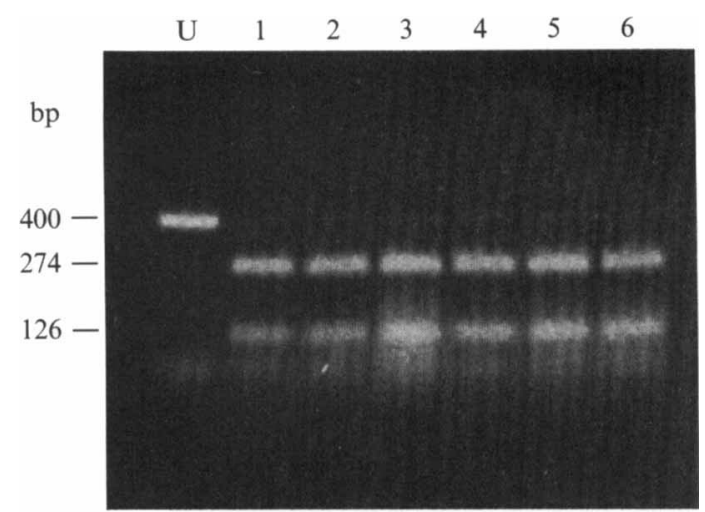

Fig. 2. Restriction enzyme analysis of the $400 \mathrm{bp}$ amplification products of six $V$. parahaemolyticus isolates. The amplification products were digested with Hinf I, subjected to electrophoresis on agarose gels and stained with ethidium bromide. Lanes: U, PCR products of $V$. parahaemolyticus A92; 1-6, V. parahaemolyticus A92 nos 14, 17, 58, 59 and 60 , respectively, which had the $t d h$ gene.

Table 2. Results of PCR, TDH assay and the DNA hybridization test used to analyse strains of Vibrio parahaemolyticus and other organisms

\begin{tabular}{lcccc}
\hline \hline $\begin{array}{l}\text { No. of strains } \\
\text { (environmental/clinical) }\end{array}$ & PCR $^{*}$ & $\begin{array}{c}\text { TDH } \\
\text { assay } \dagger\end{array}$ & $\begin{array}{c}\text { DNA } \\
\text { hybridization } \\
\text { test }\end{array}$ \\
\hline V. parahaemolyticus & $36(1 / 35)$ & + & + & + \\
& $87(85 / 2)$ & - & - & - \\
Other Vibrio spp. & $2(1 / 1)$ & + & - & + \\
& 14 & - & ND & - \\
Other genera & $1 \|$ & - & + & $+{ }^{w}$ \\
\hline \hline
\end{tabular}

ND, Not done.

* + , A specific 400 bp fragment was found by gel electrophoresis; -, the specific 400 bp fragment was not found.

$\dagger+$, Strains producing TDH; - , strains not producing TDH.

$\ddagger$ Colony or dot hybridization test performed as described in the text with a polynucleotide probe specific to the $t d h$ gene. + , The $t d h$ gene was present; - , the $t d h$ gene was absent; $+{ }^{w}$, the $t d h$-like gene was present.

$\S V$. hollisae.

$\| V$. cholerae non-01.

\section{Specificity of primers for detection of th gene in V. parahaemolyticus}

To validate the specificity of the assay, PCR amplification was performed on 125 clinical and environmental strains of $V$. parahaemolyticus and 46 other bacterial strains, using purified chromosomal DNA as a template. DNA hybridization with a polynucleotide probe specific to the $t d h$ gene (Nishibuchi et al., 1985) was also performed as described in Methods (Table 2). A $400 \mathrm{bp}$ PCR product was obtained from $38 \mathrm{~V}$. parahaemolyticus

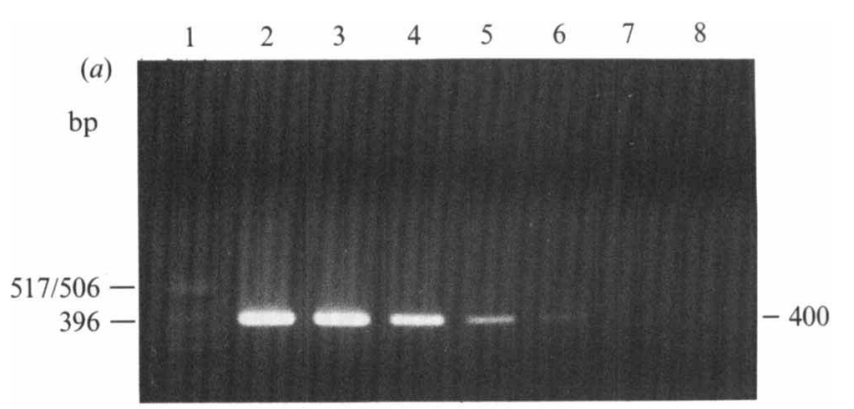

(b)

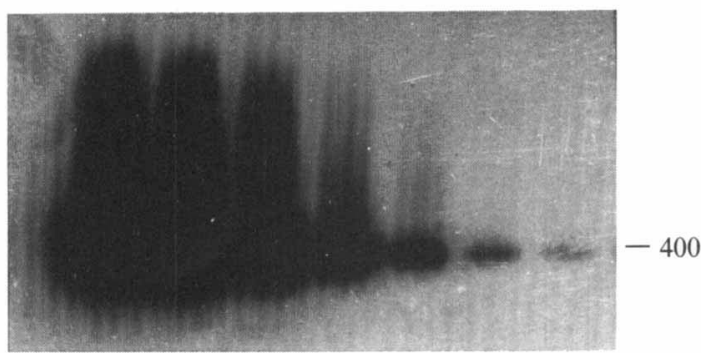

Fig. 3. Sensitivity of the PCR assay of purified DNA from $V$. parahaemolyticus A92. Lane 1: pBR322 was digested with Hinf I as DNA size marker. The amounts of total DNA used for the PCR were $400 \mathrm{ng}, 40 \mathrm{ng}, 4 \mathrm{ng}, 400 \mathrm{pg}, 40 \mathrm{pg}, 4 \mathrm{pg}, 0.4 \mathrm{pg}$ (lanes 2-8, respectively). (a) Agarose gel electrophoresis of PCR product; (b) Southern blot of the products probed with VP5.

strains which carried the $t d h$ gene. This was in agreement with the results of DNA hybridization. Of the 38 strains, 36 produced TDH as determined by bead ELISA assays (Nisui). In contrast, under the same assay conditions, a PCR product was not obtained from $87 \mathrm{~V}$. parahaemolyticus strains, 36 strains representing other Vibrio species and 10 strains of other genera (Table 2).

\section{Comparison of sample treatments for PCR sensitivity}

To test the sensitivity of the PCR assay in detecting the $t d h$ gene, three methods of sample treatment for PCR assay were compared. Chromosomal DNA extracted from a strain of $V$. parahaemolyticus carrying the $t d h$ gene was adjusted to a concentration of $80 \mu \mathrm{g} \mathrm{ml}^{-1}$, serially diluted 10 -fold in TE buffer, and $5 \mu$ l of each dilution was used as a template in the PCR analysis. The amplified product was subjected to agarose gel analysis and was also hybridized with the VP5 probe, confirming correct amplification. As shown in Fig. 3, the PCR assay detected as little as $40 \mathrm{pg}$ and $0.4 \mathrm{pg}$ DNA as the initial template in the agarose gel and Southern blot analysis, respectively.

$V$. parahaemolyticus A92 $\left(t d h^{+} t r h^{-}\right)$was grown for $1 \mathrm{~h}$ and serially diluted in $\mathrm{TSB} / 3 \% \mathrm{NaCl}$. Each serial dilution was plated on to $\mathrm{TSA} / 3 \% \mathrm{NaCl}$ plates and grown overnight at $37^{\circ} \mathrm{C}$ to determine the number of bacteria in each dilution. Simultaneously, $5 \mu$ l of the 


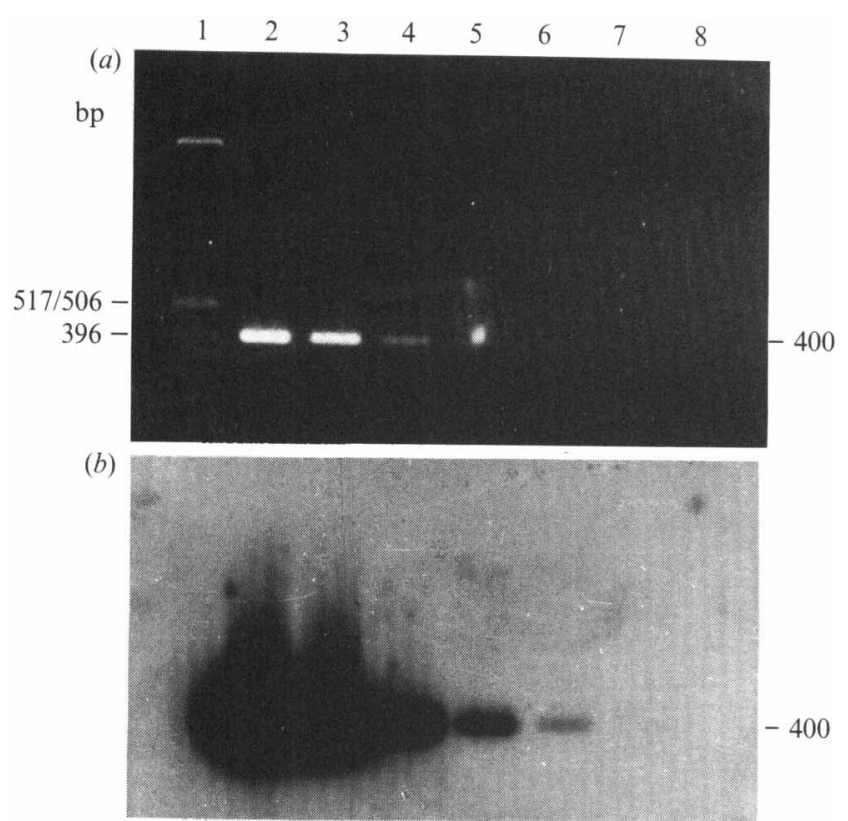

Fig. 4. Sensitivity of PCR assay using crude DNA prepared from $10^{5}$ to 1 viable cells of $V$. parahaemolyticus A92. (a) Agarose gel electrophoresis of PCR product. (b) Southern blot analysis of the products probed with VP5. Lanes: 1, molecular size markers (pBR322 digested with $\operatorname{HinfI}$ ) ; 2 , positive control ; 3-8, the number of viable cells present in each of the initial PCR mixtures was $10^{5}, 10^{4}, 10^{3}, 10^{2}, 10$, and 1 , respectively.

serially-diluted cultures were subjected to PCR analysis. The sensitivity limit of the PCR assay in detecting $t d h$ genes in $V$. parahaemolyticus was found to be between $10^{3}$ and $10^{2}$ cells, when using a crude preparation of samples as the template (Fig. 4). The sensitivity limit of PCR analysis by directly using bacterial broth as a template was similar to the results from using a crude preparation of DNA in the PCR assay.
Detection of th gene in Vibrio parahaemolyticus from stool samples by using PCR

Stool samples from seven patients with Vibrio parahaemolyticus gastroenteritis confirmed by culture and TDH were subjected to PCR amplification using VP21 and VP22 primers. Amplification of a $400 \mathrm{bp}$ product was obtained in all seven samples (Fig. $5 a$ ). Southern blot hybridization with a ${ }^{32} \mathrm{P}$-labelled internal probe (VP5) showed the same pattern and confirmed the agarose gel results (Fig. $5 b$ ). Six out of seven of these samples (Fig. 5 , lanes 1-6) did not yield a positive result unless diluted $1: 10$ prior to PCR amplification.

\section{Discussion}

A PCR protocol able to detect TDH-producing $V$. parahaemolyticus strains is reported here. VP21 and VP22 primers specifically differentiated TDH-producing and non-producing strains of $V$. parahaemolyticus. The sensitivity limit of the PCR assay with three methods of sample treatment revealed that DNA extraction and purification, or crude DNA extraction from $V$. parahaemolyticus was not necessary for the PCR assay to work satisfactorily. In addition, it was found that the bacterial culture used directly for the PCR assay without further processing yielded similar results. The results showed that not less than $10^{3}$ c.f.u. of bacteria was necessary for the detection of a product amplified after 25 PCR cycles and analysed by agarose gel electrophoresis. It is likely that fewer than this number of bacteria would be detectable by additional PCR cycles (Nakajima et al., 1992; Shirai et al., 1991; C. Y. Lee \& S.-F. Pan, unpublished data).

Recent reports have provided some methods of rapid detection of $V$. parahaemolyticus, including an improved

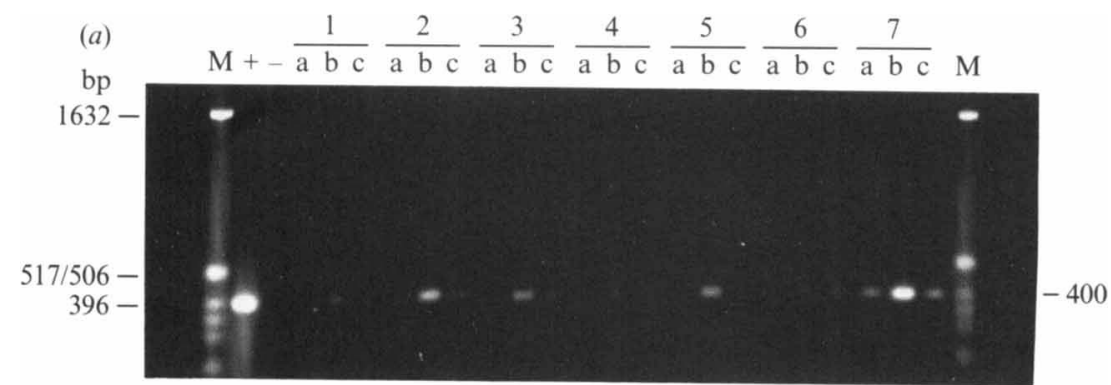

(b)

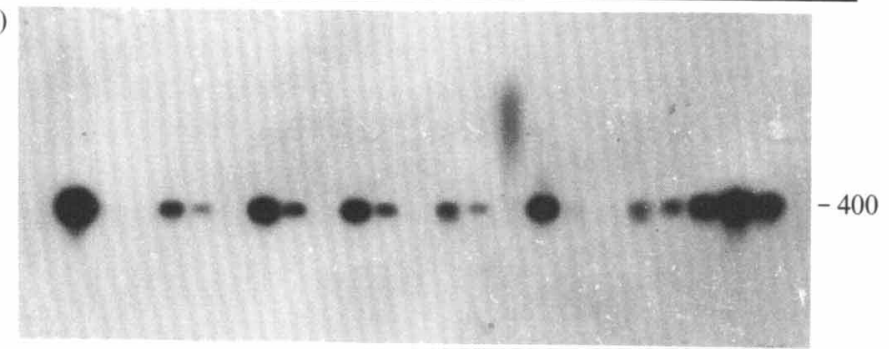

Fig. 5. Amplification of $V$. parahaemolyticus $t d h$ gene in the faecal samples from seven patients with gastroenteritis caused by $V$. parahaemolyticus. (a) Agarose gel electrophoresis of PCR product. (b) Southern blot analysis of the products probed with VP5. Lanes: M, molecular size markers (pBR322 digested with Hinf I);,$+ V$. parahaemolyticus $\mathrm{A} 92$ as a positive control; -, reagent control; $1-7$, stool samples from seven patients. Each of the stool samples was diluted 1:1 (lane a), 1:10 (lane b) or 1:100 (lane c). 
fluorogenic assay (Miyamoto et al., 1990), development of the immunomagnetic enrichment method selective for $V$. parahaemolyticus serotype K (Tomoyasu, 1992) and the oligonucleotide probe method (Lee et al., 1992); however, these methods did not distinguish TDH- and TRH-producing strains of $V$. parahaemolyticus. It has been established that TDH is an important virulence factor contributing to the enteropathogenesis of $V$. parahaemolyticus (Nishibuchi et al., 1992). Our previous studies have also shown that $95 \%$ (36 of 38) of clinical isolates from the Taiwan area were $t d h^{+}$ V. parahaemolyticus (unpublished data). Strains of $V$. parahaemolyticus carrying the $t d h$ gene have the potential to cause gastroenteritis. Thus, a rapid and sensitive method for detecting $t d h$ genes in strains of haemolytic $V$. parahaemolyticus associated with human disease is necessary as a tool for clinical laboratories.

In the present study, 125 strains of $V$. parahaemolyticus were tested by PCR with the primers VP21 and VP22, and the results were compared with those of DNA hybridization tests with an internal, polynucleotide DNA probe for the $t d h$ genes. The results indicated that all PCR-positive strains were $t d h$ positive. Immunological methods for the detection of TDH (bead ELISA assay) showed good correlation with PCR results. All but two PCR-positive strains produced TDH that was detectable in the bead ELISA assay. This false negative result observed with TDH bead ELISA assay might be due to poor haemolysin production (Yamamoto et al., 1992).

Recently, TRH, a putative virulence factor that may play a similar role in the pathogenesis of $V$. parahaemolyticus has been reported (Shirai et al., 1990). The structural genes for TDH and TRH share as much as $68 \%$ homology (Nishibuchi et al., 1989). The primers described in this paper were designed to anneal to areas of the $t d h$ but not the $t r h$ genes and would be expected to distinguish them. Several different Vibrio spp., such as non-O1 $V$. cholerae, $V$. mimicus, $V$. hollisae, were reported to possess $t d h$-like genes that hybridize with the tdh gene (Honda et al., 1986; Nishibuchi et al., 1985, 1988). Tada et al. (1992) recently reported a PCR assay for the $t d h$ gene of $V$. parahaemolyticus, but their PCR primers also gave positive results for some strains of non$\mathrm{O} 1 V$. cholerae and $V$. mimicus which possessed the $t d h$-like gene. We found that the primers used in this study did not amplify DNA from non-O1 $V$. cholerae and $V$. hollisae (Table 2). These strains can produce haemolysins and cross react with TDH of $V$. parahaemolyticus (Yoh et al., 1986, 1989).

The direct identification of haemolytic $V$. parahaemolyticus from stool samples by using PCR to amplify the $t d h$ gene without prior isolation of the microorganism should facilitate rapid diagnosis and treatment. Several researchers have reported that some inhibitory compounds in stools, such as bilirubin and bile salts, will disturb PCR amplification (Widjojoatmodjo et al., 1992; Tada et al., 1992), but other studies have revealed that the PCR method can be applied directly to stool samples (Pollard et al., 1990). Since high level of template usually inhibits the PCR reaction, a proper dilution of stool samples is required. A 10 -fold dilution of stool samples was adequate in this study (Fig. 5).

The practical value of using PCR on clinical samples is the detection of Vibrio parahaemolyticus tdh gene in the stool of patients with Vibrio parahaemolyticus gastroenteritis. Tada et al. (1992) amplified $t d h$ and trh gene sequences specifically from Vibrio parahaemolyticus, but there have been no previous reports of a successful detection of the Vibrio parahaemolyticus $t d h$ gene in clinical samples by use of PCR. In our study, the PCR performed on stool samples successfully detected the Vibrio parahaemolyticus $t$ th gene in all seven samples. The PCR could detect the $V$. parahaemolyticus $t d h$ gene in normally prepared stool samples. By using this pair of primers and the PCR protocol, amplification of the $t d h$ gene of $V$. parahaemolyticus can be achieved from the stools of infected patients. The whole procedure for identification of TDH-producing $V$. parahaemolyticus in stool samples using PCR and agarose gel electrophoresis of amplified DNA took less than $8 \mathrm{~h}$, demonstrating the PCR to be a simple, specific and rapid method for the early diagnosis of TDH-producing $V$. parahaemolyticus. This should enable accurate detection of an outbreak of gastroenteritis caused by $V$. parahaemolyticus.

This work was supported by grant FS81-10 from the Department of Health, Executive Yuan, and in part by the National Science Council, NSC81-0409-B002-69, Taipei, Taiwan, R.O.C. We gratefully thank M. Nishibuchi for kindly providing bacterial strains and Y. S. Lee and C. L. Lee, National Institute of Preventive Medicine, Department of Health, Taiwan, Republic of China, for the supply of clinical stool specimens.

\section{References}

Ausubel, F. M., Brent, R., Kingston, R. E., Moore, D. D., Seidman, J. G., Smith, J. A. \& Struhl, K. (1987). Current Protocols in Molecular Biology. New York: John Wiley.

Chiou, A., Chen, L. H. \& Chen, S. K. (1991). Foodborne illness in Taiwan 1981-1989. Food Australia 43, 70-71.

FeinberG, A. P. \& Vogelstein, B. (1984). A technique for radiolabelling DNA restriction endonuclease fragments to high specific activity. Analytical Biochemistry 137, 266-267.

Honda, T., Nishibuchi, M., Miwatani, T. \& Kaper, J. B. (1986). Demonstration of a plasmid-borne gene encoding a thermostable direct hemolysin in Vibrio cholerae non-O1 strains. Applied and Environmental Microbiology 52, 1218-1220.

Honda, T., Ni, Y., Yoh, M. \& Miwatani, T. (1989). Production of monoclonal antibodies against thermostable direct hemolysin of Vibrio parahaemolyticus and application of the antibodies for enzyme-linked immunosorbent assay. Medical Microbiology and Immunology 178, 245-253.

Kato, N., Ou, C. Y., Kato, H., Bartley, S. L., Brown, V. K., Dowell, V. R., JR \& UENo, K. (1991). Identification of toxigenic 
Clostridium difficile by the polymerase chain reaction. Journal of Clinical Microbiology 29, 33-37.

Lee, C. Y., Chen, L. H., LiU, M. L. \& Su, Y. C. (1992). Use of an oligonucleotide probe to detect Vibrio parahaemolyticus in artificially contaminated oysters. Applied and Environmental Microbiology 58, 3419-3422.

Miwatani, T. \& Takeda, Y. (1976). Vibrio parahaemolyticus: Causative Bacterium of Food Poisoning, chapter 1, Discovery of Vibrio parahaemolyticus, pp. 1-5. Tokyo: Saikon Publishing Co.

Miyamoto, Y., Kato, T., Obara, Y., Akiyama, S., Takizawa, K. \& YAMAI, S. (1969). In vitro hemolytic characteristics of Vibrio parahaemolyticus: its close correlation with human pathogenicity. Journal of Bacteriology 100, 1147-1149.

Miyamoto, T., Miwa, H. \& Hatano, S. (1990). Improved fluorogenic assay for rapid detection of Vibrio parahaemolyticus in foods. Applied and Environmental Microbiology 56, 1480-1484.

Nakajima, H., Inoue, M., Mori, T., Itoh, K. I., Arakawa, E. \& Watanabe, H. (1992). Detection and identification of Yersinia pseudotuberculosis and pathogenic Yersinia enterocolitica by an improved polymerase chain reaction method. Journal of Clinical Microbiology 30, 2484-2486.

NishibuCHI, M. \& KAPER, J. B. (1985). Nucleotide sequence of the thermostable direct hemolysin gene of Vibrio parahaemolyticus. Journal of Bacteriology 162, 558-564.

Nishibuchi, M., Ishibashi, M., TAKeda, Y. \& KAPER, J. B. (1985). Detection of the thermostable direct hemolysin gene and related DNA sequences in Vibrio parahaemolyticus and other Vibrio species by the DNA colony hybridization test. Infection and Immunity 49. $481-486$.

Nishibuchi, M., Hill, W. E., Zon, G., Payne, W. L. \& Kaper, J. B. (1986). Synthetic oligodeoxyribonucleotide probes to detect Kanagawa phenomenon-positive Vibrio parahaemolyticus. Journal of Clinical Microbiology 23, 1091-1095.

Nishibuchi, M., Doke, S., Tolzumu, S., Umeda, T., Yoh, M. \& MiWATANI, T. (1988). Isolation from a coastal fish of Vibrio hollisae capable of producing a hemolysin similar to the thermostable direct hemolysin of Vibrio parahaemolyticus. Applied and Environmental Microbiology 54, 2144-2146.

Nishibuchi, M., Taniguchi, T., Misawa, T., KhaeOmanee-I., V., Honda, T. \& Miwatani, T. (1989). Cloning and nucleotide sequence of the gene $(t r h)$ encoding the hemolysin related to the thermostable direct hemolysin of Vibrio parahaemolyticus. Infection and Immunity 57, 2691-2697.

Nishibuchi, M., Fasano, A., Russell, R. G. \& Kaper, J. B. (1992). Enterotoxigenicity of Vibrio parahaemolyticus with and without genes encoding thermostable direct hemolysin. Infection and Immunity 60, 3539-3545.

Pollard, D. R., Johnson, W. M., Lior, H., Tyler, S. D. \& Rozee, K. R. (1990). Detection of the aerolysin gene in Aeromonas hydrophila by the polymerase chain reaction. Journal of Clinical Microbiology 28, 2477-2481.

REED, K. C. \& MANN, D. A. (1985). Rapid transfer of DNA from agarose gels to nylon membranes. Nucleic Acids Research 13, $7207-7221$.
Sarkar, B. L., Kumar, R., De, S. P. \& Pal, S. C. (1987). Hemolytic activity of and lethal toxin production by environmental strains of Vibrio parahaemolyticus. Applied and Environmental Microbiology 53, 2696-2698

Shirai, H., Ito, H., Hirayama, T., Nakamoto, Y., Nakabayashi, N., KumaGaI, K., TaKeda, Y. \& NishibUChI, M. (1990). Molecular epidemiologic evidence for association of thermostable direct hemolysin (TDH) and TDH-related hemolysin of Vibrio parahaemolyticus with gastroenteritis. Infection and Immunity 58, 3568-3573.

Shirai, H., Nishibuchi, M., Ramamurthy, T., Bhattacharya, S. K., PAL, S. C. \& TAKedA, Y. (1991). Polymerase chain reaction for detection of the cholera enterotoxin operon of Vibrio cholerae. Journal of Clinical Microbiology 29, 2517-2521.

Stein, A. \& RaOUlt, D. (1992). Detection of Coxiella burnetii by DNA amplification using polymerase chain reaction. Journal of Clinical Microbiology 30, 2462-2466.

Tada, J., Ohashi, T., Nishimura, N., Shirasaki, Y., Ozaki, H., Fukushima, S., Takano, J., Nishibuchi, M. \& Takeda, Y. (1992). Detection of the thermostable direct hemolysin gene $(t d h)$ and the thermostable direct hemolysin-related hemolysin gene ( $t r h)$ of Vibrio parahaemolyticus by polymerase chain reaction. Molecular and Cellular Probes 6, 477-487.

Taniguchi, H., Ohta, H., Ogawa, M. \& Mizuguchi, Y. (1985). Cloning and expression in Escherichia coli of Vibrio parahaemolyticus thermostable direct haemolysin and thermolabile hemolysin genes. Journal of Bacteriology 162, 510-515.

Taniguchi, H., Kubomura, S., Hirano, H., Mizue, K., Ogawa, M. \& Mizuguchi, Y. (1990). Cloning and characterization of a gene encoding a new thermostable haemolysin from Vibrio parahaemolyticus. FEMS Microbiology Letters 67, 339-346.

Tomoyasu, T. (1992). Development of the immunomagnetic enrichment method selective for Vibrio parahaemolyticus serotype $\mathrm{K}$ and its application to food poisoning study. Applied and Environmental Microbiology 58, 2679-2682.

Victor, T., Du Toit, R., VAnzyl, J., Bester, A. J. \& Van Helden, P. D. (1991). Improved method for the routine identification of toxigenic Escherichia coli by DNA amplification of a conserved region of the heat-labile toxin A subunit. Journal of Clinical Microbiology 29, 158-161.

Widjojoatmodjo, M. N., Fluit, A. C., Torensma, R., Verdonk, G. P. H. T. \& VERHOEF, J. (1992). The magnetic immuno polymerase chain reaction assay for direct detection of Salmonellae in fecal samples. Journal of Clinical Microbiology 30, 3195-3199.

Yamamoto, K., Honda, T. \& Miwatani, T. (1992). Enzyme-labeled oligonucleotide probes for detection of the genes for thermostable direct hemolysin (TDH) and TDH-related hemolysin (TRH) of Vibrio parahaemolyticus. Canadian Journal of Microbiology 38, 410-416.

Yoh, M., Honda, T. \& Miwatani, T. (1986). Purification and partial characterization of a Non-O1 Vibrio cholerae hemolysin that crossreacts with thermostable direct hemolysin of Vibrio parahaemolyticus. Infection and Immunity 52, 319-322.

Yoh, M., Honda, T., Miwatani, T., Tsunasawa, S. \& Sakiyama, F. (1989). Comparative amino acid sequence analysis of hemolysins produced by Vibrio hollisae and Vibrio parahaemolyticus. Journal of Bacteriology 171, 6859-6861. 